\title{
Isolation of Bacteriophage against Currently Circulating Strains of Acineto- bacter baumannii
}

\author{
Jane F Turton ${ }^{1 *}$, Claire Perry ${ }^{1}$ and Matthew J Hannah ${ }^{2}$ \\ ${ }^{1}$ Laboratory of HealthCare Associated Infection, Centre for Infections, Health Protection Agency, 61, Colindale Avenue, London NW9 5EQ, United Kingdom \\ ${ }^{2}$ Virus Reference Department, Health Protection Agency, 61, Colindale Avenue, London NW9 5EQ, United Kingdom
}

\begin{abstract}
We successfully isolated bacteriophage active against clinical strains of Acinetobacter baumannii by enrichichment from activated sewage sludge using representatives of those strains. Purified bacteriophage suspensions obtained were tested on a range of clinical isolates that included representatives of multiple strains of each of the international clonal lineages, as well as minor and sporadic strains. Most representatives of the South East clone, a successful sublineage belonging to international clone $\mathrm{II}$, and a representative of a further strain belonging to international clone II were susceptible to the phage, while further strains belonging to this lineage, as well as those from other lineages were not susceptible. Examination by transmission electron microscopy revealed bacteriophage of the Myoviridae family. Activated sewage sludge is a valuable source of bacteriophages active against some currently circulating strains of $A$. baumannii.
\end{abstract}

Keywords: Acinetobacter baumannii; Bacteriophage; Activated sewage sludge; Typing

Abbreviations: PFGE: Pulsed-Field Gel Electrophoresis; VNTR: Variable Number Tandem Repeat; PFU: Plaque Forming Unit; SSC: 0.15 M Sodium Chloride, 0.015 M Sodium Citrate; EM: Electron Microscopy; HEPES: 4-(2-hydroxyethyl)-1-piperazineethanesulfonic acid; NCCLS: National Committee for Clinical Laboratory Standards; BSAC: British Society for Antimicrobial Chemotherapy; UK: United Kingdom; h: Hour

\section{Introduction}

Acinetobacter baumannii is an opportunistic pathogen, mainly affecting patients in intensive care units, that is usually resistant to most antibiotics. Infections can occur at any body site, but the organism is mainly associated with ventilator-associated pneumonia, catheter-related bloodstream and urinary tract infections, and wound infections [1]. Most clinical isolates belong to one of two major lineages, known as international clones I and II $[2,3]$, which can be further divided into 'sublineages' by techniques such as pulsed-field gel electrophoresis (PFGE). Some of these sublineages are highly successful, and have affected large numbers of patients in multiple hospitals. The multiresistance has sparked fears that there may shortly be no therapeutic agents to combat infections with this organism, leading to a revival of interest in bacteriophage as a potential therapeutic agent [4-6]. Recently, there have been four reports of bacteriophages that are active against A. baumannii, but their host range is usually limited, with only a proportion of isolates tested being susceptible [7-10]. In the study of Lee et al. [10], only $27 \%$ of isolates tested were susceptible to bacteriophage Abp53, whilst in that of Yang et al. [8], no other hosts tested were susceptible to bacteriophage $\mathrm{AB} 1$, indicating a narrow host range. The use of a cocktail of bacteriophages is therefore sometimes advocated $[8,11]$. Moreover, the bacteriophages in these studies have mostly been from environmental sources, when it is clear that clinical strains of A. baumannii affecting patients are not found in the general environment. This has led us to consider the possibility of looking for bacteriophages in activated sewage sludge using particular clinical isolates and strains, to considerably increase the chance of obtaining bacteriophage to which that strain would be susceptible. 'Activated' in the term 'activated sewage sludge' refers to the mixing of collected sludge, that is rich in bacteria, with incoming effluent and air, to degrade the organic material.
Here we describe the results of this approach, and suggest that activated sewage sludge is a valuable source of bacteriophages for custom treatment of individual strains, which could be drawn upon in specific cases, or to update bacteriophage cocktails for activity against commonly isolated, currently circulating strains.

\section{Materials and Methods}

In June 2010 a fresh sample of approximately 1 litre of activated sewage sludge was obtained from Thames Water (Mogden Sewage Works, Isleworth, London) and allowed to settle. For each A. baumannii strain to be tested, approximately $1.25 \mathrm{~g}$ of the sediment was added to $5 \mathrm{ml}$ of nutrient broth, and this was inoculated with $50 \mu \mathrm{l}$ of overnight culture of the bacteria and incubated with shaking for $6 \mathrm{~h}$ at $37^{\circ} \mathrm{C}$. The culture was centrifuged at $1,000 \mathrm{x}$ g for $2 \mathrm{~min}$ and the resulting supernatant filtered through a $0.45 \mu \mathrm{m}$ filter into a sterile bijou. This preparation was then tested against the host strains used. Overnight cultures of each strain were poured onto dried nutrient agar or SSC $(0.15 \mathrm{M}$ sodium chloride, $0.015 \mathrm{M}$ sodium citrate) plates, and, once the plate had been covered completely, the excess liquid was removed. SSC was used in some of the first experiments to prevent potential overgrowth of the plaque clearings by the bacterial lawn. Plates were left to dry for approximately $2 \mathrm{~h}$. A drop (approximately $20 \mu \mathrm{l}$ ) of the filtered supernatant from each of the cultures grown with sediment was added and the plates incubated at $30^{\circ} \mathrm{C}$ overnight. The following day, they were examined for plaques (clear circular zones in otherwise confluent bacterial growth due to lysis of the bacteria by bacteriophage). Preparations that had yielded plaques were serially diluted in nutrient broth to $10^{-6}$ and 100 $\mu \mathrm{l}$ of each dilution added to $300 \mu \mathrm{l}$ of exponential phase host cells in

${ }^{*}$ Corresponding author: Laboratory of HealthCare Associated Infection, Centre for Infections, Health Protection Agency, 61, Colindale Avenue, London NW9 5EQ, United Kingdom Tel: +44 (0)208 327 7224; Fax: +44(0)208 200 7449, E-mail: jane.turton@hpa.org.uk

Received April 03, 2012; Accepted May 08, 2012; Published May 14, 2012

Citation: Turton JF, Perry C, Hannah MJ (2012) Isolation of Bacteriophage against Currently Circulating Strains of Acinetobacter baumannii. J Med Microb Diagn 1:109. doi:10.4172/2161-0703.1000109

Copyright: (c) 2012 Turton JF, et al. This is an open-access article distributed under the terms of the Creative Commons Attribution License, which permits unrestricted use, distribution, and reproduction in any medium, provided the original author and source are credited. 
an Eppendorf tube, incubated at $37^{\circ} \mathrm{C}$ for $5 \mathrm{~min}$ in a heated block and the mixture added to $4 \mathrm{ml}$ of top agar $(0.6 \%(\mathrm{w} / \mathrm{v})$ agarose in nutrient broth) at $45^{\circ} \mathrm{C}$, and poured immediately onto nutrient agar plates. Plates were incubated at $30^{\circ} \mathrm{C}$ overnight, and those that had yielded plaques sufficiently separated to facilitate picking of single plaques chosen for plaque purification.

After two rounds of plaque purification, preparations were plated with their host strain to give near confluent plaques, and the top agar scraped off into nutrient broth. Following filtration through a $0.45 \mu \mathrm{m}$ filter, the titre of the bacteriophages was determined (by serial dilution and plating as above) and suspensions containing $1 \times 10^{5} \mathrm{pfu} / \mathrm{ml}$ prepared by dilution in nutrient broth for testing against a large number of previously characterized clinical isolates. In some experiments, $\mathrm{MgSO}_{4}$ was added to a final concentration of $10 \mathrm{mM}$ to the nutrient broth used for dilutions and in the top agar overlay to ensure that any apparent lack of susceptibility shown by particular hosts was not the result of suboptimum concentrations of divalent cations in the media used.

\section{Bacterial isolates}

A. baumannii isolates had been received from hospitals in the UK and abroad, and had all been characterized by a combination of PCR analysis (for OXA carbapenemase genes, class 1 integrase gene and Group 1 (international clone II) bla OXA-51-like, $_{1} c s u E$ and ompA alleles), pulsed-field gel electrophoresis of ApaI-digested genomic DNA and analysis at two Variable Number Tandem Repeat (VNTR) loci, as described previously $[3,12]$. They included representatives of strains of all three international lineages, as well as sporadic strains. Where multiple representatives of the same strain were included, these were chosen to be each from a different patient and hospital.

\section{Electron microscopy}

Bacteriophage suspensions were concentrated by centrifugation, resuspended in $10 \mathrm{mM}$ 4-(2-hydroxyethyl)-1-piperazineethanesulfonic acid (HEPES) pH 7.4 and examined by transmission electron microscopy (EM) after negative staining on-grid with $1.5 \%$ phosphotungstic acid. The electron microscope camera was calibrated and regularly checked using commercially available size standards (diffraction gratings and catalase crystals purchased from Agar Scientific, Stansted, UK).

\section{Results and Discussion}

Initial experiments involved culturing representatives of four, distinct strains of A. baumannii, detailed in Table 1a, with the activated sewage sludge sediment and testing the resulting supernatants for activity against these same isolates. This resulted in enrichment of phage against two of them, both of which were representatives of strains belonging to the international clone II lineage, that have affected multiple patients $[3,13]$. On the basis of the appearance of the bacteriophages by $\mathrm{EM}$, and the pattern of susceptibility of the bacterial isolates, the enriched phage was the same from both hosts. Plaque purification was carried out using these isolates, and a further three hosts identified during testing, with suspensions purified from each being tested in parallel.

\begin{tabular}{|l|l|l|}
\hline Isolate & International clonal \\
\hline $\begin{array}{l}\text { PFGE type/(isolate } \\
\text { number) }\end{array}$ & $\begin{array}{l}\text { Susceptible to phage in sedi- } \\
\text { lineage }\end{array}$ & No \\
\hline OXA-23 clone $1(1)^{2}$ & II & Yes \\
\hline North West strain $(1)^{3}$ & II & Yes \\
\hline South East clone $(1)^{2}$ & II & No \\
\hline Burns Unit strain $(1)^{2}$ & I & \\
\hline
\end{tabular}

a) Original four isolates grown in presence of sediment:

\begin{tabular}{|c|c|c|}
\hline PFGE type ${ }^{1}$ & International clonal lineage & $\begin{array}{l}\text { Proportion of representa- } \\
\text { tives tested susceptible to } \\
\text { bacteriophage }\end{array}$ \\
\hline South East clone ${ }^{4}$ & II & $8 / 9$ \\
\hline North West strain ${ }^{3}$ & II & $1 / 2$ \\
\hline OXA-23 clone $1^{2}$ & II & $0 / 8$ \\
\hline T-strain & II & $0 / 1$ \\
\hline SAC-1 & II & $0 / 2$ \\
\hline QAC-9² & II & $0 / 1$ \\
\hline WM (Australia 2) ${ }^{2}$ & II & $1 / 1$ \\
\hline Other strains & II & $0 / 2$ \\
\hline QAC-16 ${ }^{2}$ & 1 & $0 / 1$ \\
\hline AYE strain & 1 & $0 / 1$ \\
\hline Burns Unit strain² & I & $0 / 2$ \\
\hline QAC-24² & 1 & $0 / 1$ \\
\hline CAC $-9^{2}$ & I & $0 / 1$ \\
\hline Midlands 2 & III & $0 / 1$ \\
\hline Sporadic strains & - & $0 / 3$ \\
\hline
\end{tabular}

b) Testing panel for enriched bacteriophage suspensions ${ }^{5}$

${ }^{1}$ PFGE types are as described previously (15).

${ }^{2}$ PCR positive for bla ${ }_{\text {OxA-23-like }}$ acquired carbapenemase gene.

${ }^{3}$ PCR positive for bla ${ }_{\text {OXA-23--like }}$ acquired carbapenemase gene.

${ }^{4}$ Two of the nine representatives of the South East clone tested were PCR posi-

tive for bla oxa-23 $_{\text {-ike }}$ acquired carbapenemase gene.

${ }^{5}$ Suspensions all gave the same results

Table 1: A. baumannii isolates used.

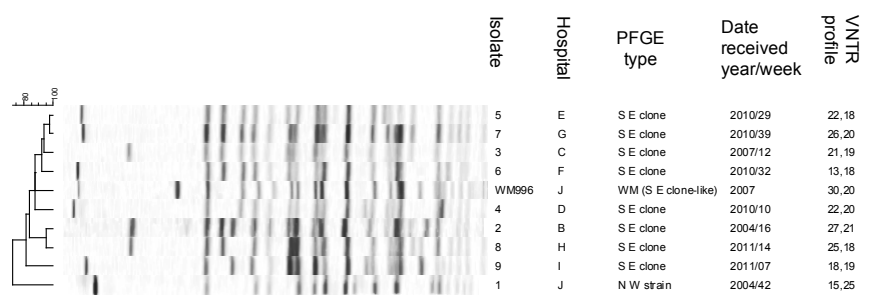

Figure 1: Dendrogram of pulsed-field gel electrophoresis profiles of Apaldigested genomic DNA of isolates susceptible to the bacteriophage. Each isolate was from a different patient and hospital, (A-I) and had a distinct Variable Number Tandem Repeat (VNTR) profile at two loci that can provide discrimination within a PFGE type, providing further evidence that the isolates were epidemiologically distinct. All susceptible isolates belonged to the international clone II lineage.

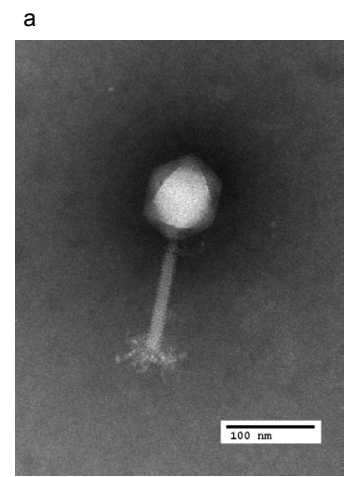

\section{b}

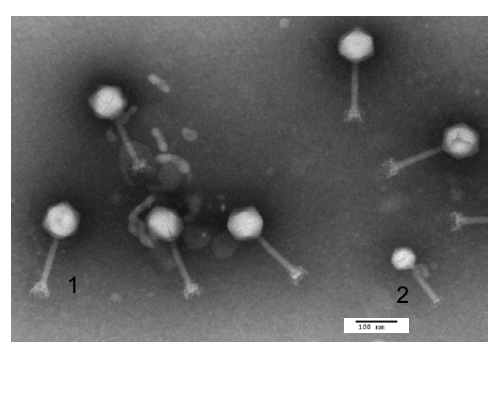

Figure 2: Electron micrographs of bacteriophage suspensions showing phage of the Myoviridae family. In b) note bacteriophage of two distinctive morphologies (labeled 1 and 2) co-enriched in isolate WM996.

Of the 36 A. baumannii isolates tested in total (the original host isolates and the further panel), which included strains belonging to each of the three international lineages and sporadic and minor strains, only 
10, all belonging to strains of international clone II, were susceptible to the phage suspensions. Representatives of the South East clone, in particular, were sensitive to the bacteriophage (8/9 isolates), as was a representative of the North West strain (Figure 1). Representatives of OXA-23 clone 1, which also belongs to international clone II, and is the most prevalent type in the UK $[12,14]$, were not susceptible $(8 / 8)$, nor were isolates of four other strains belonging to international clone II (Table 1). Results were the same irrespective of which bacterial host was used for purification, with the exception that, with one of the isolates (WM996, originating from Australia), a morphologically distinct phage (Figure $2 \mathrm{~b}$ ) was co-enriched; unfortunately we were not able to obtain pure suspensions of this putative further bacteriophage. Although zones on bacterial lawns were mostly clear, some 'spots' of growth were observed in the clear zone in some cases, suggesting emergence of resistance against the bacteriophage.

EM examination of the bacteriophage suspensions indicated bacteriophage belonging to the Myoviridae family (Figure 2).

The South East clone is one of the successful sublineages of international clone II that has affected muItiple hospitals in the UK $[13,14]$. Most current isolates carry $b l a_{\text {OXA-23-like }}$ in an AbaR4-type island inserted in the comM gene [15], and display multiresistance to antibiotics, including the carbapenems; those without $b l a_{\text {OXA-23-like }}$ often show upregulation of $b l a_{\text {OXA-51-like }}$. Indeed, isolate 2 was resistant to all antibiotics tested (amikacin (MIC $32 \mathrm{mg} / \mathrm{L}$ ), gentamicin (MIC > $32 \mathrm{mg} / \mathrm{L}$ ), tobramycin (MIC $8 \mathrm{mg} / \mathrm{L}$ ), ampicillin (MIC $>64 \mathrm{mg} / \mathrm{L}$ ), aztreonam (MIC $64 \mathrm{mg} / \mathrm{L}$ ), imipenem (MIC $16 \mathrm{mg} / \mathrm{L}$ ), meropenem (MIC $16 \mathrm{mg} / \mathrm{L}$ ), sulbactam (MIC $32 \mathrm{mg} / \mathrm{L}$ ), piperacillin (MIC $>64 \mathrm{mg} / \mathrm{L}$ ), piperacillin/ tazobactam (MIC $>64 \mathrm{mg} / \mathrm{L})$, colistin $(\mathrm{MIC}>32 \mathrm{mg} / \mathrm{L}$ ), ciprofloxacin (MIC > $8 \mathrm{mg} / \mathrm{L}$ ), ceftazidime (MIC $64 \mathrm{mg} / \mathrm{L}$ ), cefepime (MIC $32 \mathrm{mg} / \mathrm{L}$ ), cefotaxime (MIC > $64 \mathrm{mg} / \mathrm{L}$ ) and cefoxitin (MIC > $64 \mathrm{mg} / \mathrm{L}$ ); there was intermediate susceptibility to minocycline (MIC $8 \mathrm{mg} / \mathrm{L}$ ) according to National Committee for Clinical Laboratory Standards (NCCLS) criteria). A further potential therapeutic agent against this strain is therefore welcome, although caution should be advised. Increased use of bacteriophages may encourage transfer of genes by transduction, and perhaps use of bacteriophage products, such as lysins, is a safer option than using live bacteriophage [16,17]. Resistance, indicated by spotting in phage clearings on bacterial lawns, may appear.

The wide susceptibility of representatives of the South East clone, from different hospitals and outbreaks, to the bacteriophage is encouraging. Unfortunately, despite using a representative of OXA-23 clone 1 in the initial enrichment, we did not isolate bacteriophage to which this genotype, the most prevalent in the UK, was sensitive. We used an isolate dating from 2003 in this enrichment; perhaps using a more current isolate could have been more successful.

This work has shown that activated sewage sludge is a useful source of bacteriophage against some currently circulating strains of $\mathrm{A}$. baumannii. However, the host range of each bacteriophage is limited, and enrichment of phage using the strain (as here with the South East clone) for which therapy is sought greatly increases the chance of finding phage to which it will be sensitive. We have isolated a bacteriophage active against most representatives of the South East clone, a sublineage of international clone II resistant to most antibiotics that has infected many patients in UK hospitals.

\section{Acknowledgements}

We are grateful to Mark Grimshaw and Darren Crone at Thames Water, Mogden Lane, Isleworth for providing us with a sample of activated sewage sludge, without which this work would not have been possible.

\section{References}

1. Dijkshoorn L, Nemec A, Seifert $H$ (2007) An increasing threat in hospitals: multidrug-resistant Acinetobacter baumannii. Nat Rev Microbiol 5: 939-951.

2. Diancourt L, Passet V, Nemec A, Dijkshoorn L, Brisse S (2010) The population structure of Acinetobacter baumannii: expanding multiresistant clones from an ancestral susceptible genetic pool. PLoS One 5: e10034.

3. Turton JF, Gabriel SN, Valderrey C, Kaufmann ME, Pitt TL (2007) Use of sequence-based typing and multiplex PCR to identify clonal lineages of outbreak strains of Acinetobacter baumannii. Clin Microbiol Infect 13: 807-815.

4. Mihu MR, Martinez LR (2011) Novel therapies for treatment of multi-drug resistant Acinetobacter baumannii skin infections. Virulence 2: 97-102.

5. Matsuzaki S, Rashel M, Uchiyama J, Sakurai S, Ujihara T, et al. (2005) Bacteriophage therapy: a revitalized therapy against bacterial infectious diseases. J Infect Chemother 11: 211-219.

6. Skurnik M, Strauch E (2006) Phage therapy: facts and fiction. Int J Med Microbiol 296: 5-14.

7. Lin NT, Chiou PY, Chang KC, Chen LK, Lai MJ (2010) Isolation and characterization of phi AB2: a novel bacteriophage of Acinetobacter baumannii. Res Microbiol 161: 308-314

8. Yang H, Liang L, Lin S, Jia S (2010) Isolation and characterization of a virulent bacteriophage AB1 of Acinetobacter baumannii. BMC Microbiol 10: 131.

9. Chang KC, Lin NT, Hu A, Lin YS, Chen LK, et al. (2011) Genomic analysis of bacteriophage $\varphi \mathrm{AB} 1$, a $\varphi \mathrm{KMV}$-like virus infecting multidrug-resistant Acinetobacter baumannii. Genomics 97: 249-255

10. Lee CN, Tseng TT, Lin JW, Fu YC, Weng SF et al. (2011) Lytic myophage Abp53 encodes several proteins similar to those encoded by host Acinetobacter baumannii and phage phiKO2. Appl Environ Microbiol 77: 6755-6762.

11. Gu J, Liu X, Li Y, Han W, Lei L et al. (2012). A method for generation phage cocktail with great therapeutic potential. PLoS One 7: e31698.

12. Turton JF, Matos J, Kaufmann ME, Pitt TL (2009) Variable number tandem repeat loci providing discrimination within widespread genotypes of Acinetobacter baumannii. Eur J Clin Microbiol Infect Dis 28: 499-507.

13. Turton JF, Kaufmann ME, Warner M, Coelho J, Dijkshoorn L, et al. (2004) A prevalent, multiresistant clone of Acinetobacter baumannii in Southeast England J Hosp Infect 58: 170-179.

14. Coelho JM, Turton JF, Kaufmann ME, Glover J, Woodford N, et al. (2006) Occurrence of carbapenem-resistant Acinetobacter baumannii clones at multiple hospitals in London and Southeast England. J Clin Microbiol 44: 3623-3627.

15. Turton JF, Baddal B, Perry C (2011) Use of the accessory genome for characterization and typing of Acinetobacter baumannii. J Clin Microbiol 49: 1260-1266.

16. Lai MJ, Lin NT, Hu A, Soo PC, Chen LK, et al. (2011) Antibacterial activity of Acinetobacter baumannii phage $\varphi A B 2$ endolysin (LysAB2) against both grampositive and gram-negative bacteria. Appl Microbiol Biotechnol 90: 529-539.

17. Rashel M, Uchiyama J, Ujihara T, Uehara Y, Kuramoto S, et al. (2007) Efficient elimination of multidrug-resistant Staphylococcus aureus by cloned lysin derived from bacteriophage phi MR11. J Infect Dis 196: 1237-1247.

\section{Submit your next manuscript and get advantages of OMICS Group submissions}

Unique features:

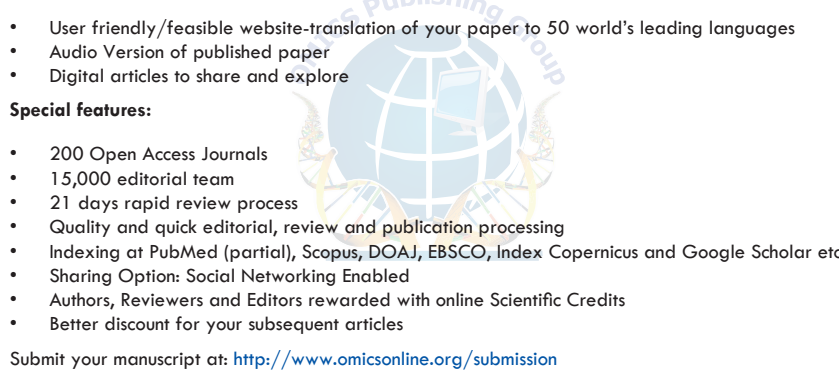

